\title{
The Effect of Management and Utilization of Productive Zakat Towards Mustahiq Empowerment
}

\author{
Romadona Adawiyah $^{1 *}$, Dinnul Alfian Akbar ${ }^{1}$, Fernando Africano ${ }^{1}$
}

\begin{abstract}
This research aims to discover the influence of management of productive zakah on the mustahiq as the BAZNAS in south sumatra province as well as influence of utilization of productive zakah on the mustahiq empowerment. Data collection method used in this research utilized questionnaire in likert scale. Wherein all of 30 residents (population) are being used as sample (census technique). The $\mathrm{F}$ test, $t$ test and the coefficient determinan $\left(\mathrm{R}^{2}\right)$ the show that management of productive zakah had a positive and significant impact on mustahiq empowerment in (BAZNAS) south sumatra province and utilization of productive zakah had a positive and significant impact on mustahiq empowerment as well.
\end{abstract}

Keywords : Management of productive zakat, utilization of productive

DOI : https://doi.org/10.30596/ijbe.v2i1.4960

JEL Classification : 004, I38, M14, D6

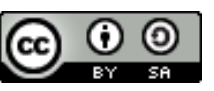

Published by International Journal of Business Economics (IJBE), Indonesia | Copyright (C)2020 by the Author(s) | This is an open access article distributed under the Creative Commons Attribution License http://creativecommons.org/licenses/by/4.0), which permitsunrestricted use, distribution, and reproduction in any medium, provided the original work is properly cited.

Cite this article as:

Adawiyah, R., Akbar, D. A., \& Africano, F. The Effect of Management and Utilization of Productive Zakat Towards Mustahiq Empowerment. International Journal of Business Economics (IJBE), 2(1), 39-51.

Universitas Islam Negeri Raden Fatah Palembang

Jl. Prof. K. H. Zainal Abidin Fikri Kota Palembang, Sumatera Selatan 30126, Indonesia

*Corresponding Author: romadona.adawiyah@gmail.com 


\section{International Journal of Business Economics (IJBE)}

Vol, 2 Issue 1, pp 39-51, Sept 2020

http://jurnal.umsu.ac.id/index.php/ijbe

eISSN 2686-472X

\section{INTRODUCTION}

Mustahiq Empowerment is an effort made to help develop potential and encourage and motivate Mustahiq to be independent in business activities carried out from productive zakat funds obtained. With this empowerment, it is expected to create understanding, awareness and shape the attitudes and behavior of people's lives towards independence. Zakat is a form of worship that can draw closer to Allah. Therefore, whatever is applied in zakat must be in accordance with its application. Zakat is required for those who are able to cover the needs of the poor and as a form of gratitude for the blessings of wealth that God has bestowed. As a main worship, zakat in Islam is the fourth pillar of the five pillars of Islam. The existence of zakat is considered as ma'lum min ad-dien bi adl-dlarurah (it is known automatically and is an absolute part of one's Islam). Zakat itself is required because it has a large role in improving the economy of a country's society (Hasanah, 2010).

Zakat management is an activity carried out by the Amil Zakat Institute (LAZ) and the Amil Zakat Agency (BAZ), one of which is the National Amil Zakat Agency (BAZNAS) by collecting, distributing and utilizing zakat. The purpose of management itself is to improve the effectiveness and efficiency of services in the management of zakat and increase the benefits of zakat to realize community welfare and poverty reduction (BAZNAS, 2016). The concept of empowerment is related to the utilization of zakat funds. Utilization of zakat funds is a form of maximum utilization of resources (zakat funds) so that they are useful to achieve benefits for the community. Utilization of productive zakat funds is directed at the goal of empowerment through various programs that have benefits for the community, especially the underprivileged Muslim community. With the help of the zakat funds they obtain, they can expand their businesses so that they will further develop which allows their income to increase and can absorb labor from the surrounding community. In the best use and utilization of zakat, zakat management agency policies are needed by involving the role of government (Departemen Agama RI, 2004).

The National Sharia Finance Committee (KNKS) explained that zakat in Indonesia has a large potential of around $\mathrm{Rp} 200$ trillion. However, optimizing the collection of zakat right now is still minimal, it can be seen through zakat funds collected and currently managed at only Rp8 trillion. This number should be greater, considering the majority of Indonesia's population is Muslim. The collection of zakat is properly done to help the management and utilization of productive zakat to be carried out properly (BAZNAS, 2019).

Table 1. Potential of Zakat in Indonesia

\begin{tabular}{cccc}
\hline Number & Year & Amount of Alms Collection & $\begin{array}{c}\text { Percentage } \\
\text { Increase }\end{array}$ \\
\hline 1 & 2016 & Rp5.017,29 Billion & $2,3 \%$ \\
2 & 2017 & Rp6.224,37 Billion & $2,8 \%$ \\
3 & 2018 & Rp8.100 Billion & $3,7 \%$ \\
\hline
\end{tabular}

Sources: Collected from various sources, 2019

The National Amil Zakat Agency (BAZNAS) is the official and only body formed by the government based on Presidential Decree No. 8 of 2001 which has the duties and functions of collecting and distributing zakat, infaq, and alms (ZIS) at the national level. Birth of Law No. 23 of 2011 concerning Management of Zakat increasingly reinforces the role of BAZNAS as an institution authorized to conduct zakat management nationally. Thus, BAZNAS together with the Government is responsible for overseeing the management of zakat that is based on: Islamic Sharia, trustworthiness, expediency, justice, legal certainty, 


\section{International Journal of Business Economics (IJBE)}

Vol, 2 Issue 1, pp 39-51, Sept 2020

http:/ /jurnal.umsu.ac.id/index.php/ijbe

eISSN 2686-472X

integrated and accountability (BAZNAS, 2019). Regarding the receipt of zakat in South Sumatra Province BAZNAS in 2019 it targets from the Muslim community in 17 regencies and cities in the local province area around Rp. 4.8 billion. Head of BAZNAS South Sumatra Province, Drs. H. Najib Haitami, MM., said that the target was optimistic that it could be achieved because in 2018 the receipt of zakat could be reached around Rp4 billion (Abdullah, 2019). Based on the results of previous studies, indicating the existence of a research gap of the independent variables that influence the empowerment of mustahiq, namely as follows:

The influence of the management of productive zakat on the empowerment of mustahiq studied by Evi Nurmalasari (Nurmalasari, 2012) shows that the management of productive zakat has a positive and significant effect on the empowerment of mustahiq. This is different from the results of research conducted by Abdul Aziz and Rizki Amaliah (Aziz dan Rizki Amaliah, 2012) which shows that the management of productive zakat has a negative effect on the empowerment of mustahiq. While the influence of the use of productive zakat on empowering mustahiq examined by Suratno (Suratno, 2017) shows that the use of productive zakat has a significant effect on the empowerment of mustahiq. This is different from the results of research conducted by Ahmad Fajri Panca Putra (Putra, 2010) which shows that the use of productive zakat has a negative effect on the empowerment of mustahiq.

The theory of "ACTORS" in community empowerment. The "ACTORS" theory of empowerment put forward by Sarah Cook and Steve Macaulay views society as a subject that can make changes by freeing someone from rigid control and giving that person the freedom to be responsible for his ideas, decisions, and actions his actions (Maani, 2011). This theoretical framework in measuring the management and utilization of productive zakat for empowering mustahiq can be seen from the acronym "ACTORS" which consists of:

$\mathbf{A}=$ authority by giving trust. Namely the group / community is given the authority to change the stance or enthusiasm (work ethic) into something that becomes their own property. Thus, they feel that the changes made are the product of their desire for better change. In this case, the one who has the authority in managing and utilizing productive zakat is the National Amil Zakat Agency (BAZNAS) as a non-structural government institution. Then the National Amil Zakat Board (BAZNAS) gives mustahiq the authority to manage and utilize the productive zakat that has been given. $\mathbf{C}=$ confidence and competence. That raises the confidence mustahiq by seeing their ability to be able to change the situation. $\quad \mathbf{T}=$ trust. That raises the belief that they (mustahiq) have the potential to change and they must be able (able) to change it. $\mathbf{O}=$ opportunities. Namely the National Amil Zakat Agency (BAZNAS) provides an opportunity for the community to choose what they want so that they can develop themselves in accordance with the potential that exists within the community itself. $\mathbf{R}=$ responsibilities. Namely in making changes made both by the National Amil Zakat Agency (BAZNAS) and mustahiq must go through management so that it is carried out with full responsibility to change for the better. $\mathbf{S}=$ support. That is the need for support from various parties to make it better. In this case the expected support apart from the economic, social and cultural side is also support from various stakeholders (government, society, and the business world) carried out simultaneously without being dominated by one of the parties / factors.

Zakat in language means blessing, growth, holiness, goodness, and cleanliness of things. Whereas zakat on the basis of 'zakat is a certain calculation of assets and the like where the shariah' requires to issue it to the needy people and others with special conditions. 


\section{International Journal of Business Economics (IJBE)}

Vol, 2 Issue 1, pp 39-51, Sept 2020

http:/ /jurnal.umsu.ac.id/index.php/ijbe

eISSN 2686-472X

The word zakat originally meant: al-thaharah (clean), al-nama '(growing, developing), albarakah (enduring grace), al madh (praiseworthy), and al-shalah (piety). All these meanings have been used both in the Qur'an and the hadith (Arifin, 2016).

\section{The group entitled to receive Zakat (Mustahiq)}

In distributing zakat, zakat distribution can only be given to eight groups (asnaf) as the word of Allah Almighty, in QS. At-Taubah (9) : 60.

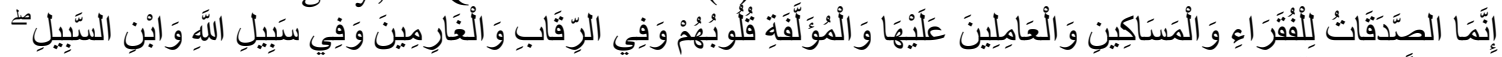

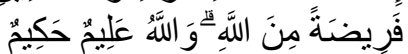

And indeed charity is only for the poor, for the poor, for charity, for persuaded believers, for the releaase of slaves, for debtorss, for the way of God and for people, for people on the road. As a provision that is demanded by God. And Allah is All-Knowing, All-Wise. (QS. AtTaubah (9) : 60).

The following is a further explanation of the eight Asnaf according to El-Madani (ElMadani, 2013). 1). Indigent, Lafadzh fuqara 'is a form (plural / plural) of the word fakir which is a person who does not have property, work, or he has property and work, but cannot fulfill his needs which include clothing, food, shelter, and the needs of people who be the responsibility.2). Poor, Poor (masakin), taken from the word "breadfruit" which has the meaning of being unable to move, is a person who is able to work with a decent job, but cannot meet his needs including food, clothing, shelter, and other needs, as well as the needs of people whose livelihood is their responsibility. 3). Amil, Amil zakat is the workers, officers, guards, collectors, and registers of zakat that have been appointed by the government in collecting zakat assets, collecting, recording, guarding, and distributing them to the mustahiq zakat. The amil may not take a certain portion of the income they get, because their wages have been adjusted to their work. 4) Converts, A convert to Arabic, the word al-mu'allafah is a plural form of the word ta'alluf which means to unite the heart. Named converts in the hope that the tendency of their hearts will be stronger against Islam, because they get a boost in the form of matter. 5). Riqab, Riqab (slave servant), there are three interpretations of the scholars regarding the meaning of this riqab. First, the mukatab slave who buys himself from his master with a number of dirhams, which is suspended in his dependents, then this person is given the zakat portion in order to pay to his master. 6). Gharim, Gharim is a person who is in debt. Ulama divide gharim into two parts, those who are in debt to reconcile the disputing parties, and those who are in debt to cover their unmet needs. 7). Fisabilillah, Fisabilillah means jihad in the way of Allah. The fighters who voluntarily strive in the way of Allah, preach, defend Islam, and fight for the country's independence. They did not get compensation and salary for their activities. 8) Ibn Sabil, In Arabic, sabil means tariq (way), while Ibn Sabil can be interpreted as a traveler. Ibn Sabil was a traveler who traveled and they ran out of food.

According to Yusuf Qardhawi, productive zakat is zakat which is managed as an effort to improve the economy of the poor by focusing on the empowerment of its resources, through research that leads to improving its skills, which in turn zakat funds become capital for business development so that they have an income to meet his needs and become independent in developing the economy (Qardhawi, 2005). The word productive comes from the English word "productive" which means it gives a lot of results, produces, produces lots of valuables, and has good results (Syahriza, 2019). 


\section{International Journal of Business Economics (IJBE)}

Vol, 2 Issue 1, pp 39-51, Sept 2020

http://jurnal.umsu.ac.id/index.php/ijbe

eISSN 2686-472X

Traditional Earning, Traditional productive zakat is zakat given in the form of productive items such as sewing machines, carpentry tools, goats, cattle, and so forth. Giving zakat in this form can encourage someone to create a business or provide employment for the poor. Creative Earning, Creative productive zakat is all utilization of zakat which is realized in the form of capital that can be used to build a social project or in terms of helping or increasing the capital of traders or small entrepreneurs (Syahriza, 2019).

According to Henry Fayol in Umrotul Khasanah, management or management can be interpreted as a process of planning, organizing, leadership, coordination, and supervision of the efforts of members of the organization and from other organizational sources to achieve the stated organizational goals (Hasanah, 2010). Management of zakat according to Law Number 23 of 2011 concerning Management of Zakat is the activity of planning, organizing, implementing, and controlling the collection, distribution and utilization of zakat (BAZNAS, 2016).

\section{Indicator of Management}

According to Robert M. Ranftl in Sugiyono, suggested effective management indicators seen from the following variables (Sugiyono, 2017). 1) Planning, Develop realistic, time-based plans for long, medium and short term. 2) Organizing and Staffing (Organizing and Staffing), Establish clear definition of function, authority, and accountability. 3) Directing, Delegate work effectively, encourage maximum employee involvement and responsibility. 4). Control / Supervision (Control), Monitor operational progress and prompt correct correct errors. 5). Communication (Communication), Maintain good intra-and inter organizational communication. 6). Procurement / Subcontracting (Procurement / Subcontracting), 7). Establish effective time-phased plans for procurement. 8). Space and Facilities, Accurately predict its space and facilities needs.

According to Yusuf Qardhawi the use of zakat is a form of maximum utilization of zakat without reducing its value and usefulness, so that it is useful for achieving the benefit of the people (Qardhawi, 2005). Utilization is an effort to be able to bring results and benefits, or an effort to be able to carry out their duties properly (Rosmawati, 2014). Utilization of zakat is principally related to the technical distribution of zakat so that it is right on target and efficient for recipients of zakat (mustahiq). In Law Number 23 of 2011 concerning Management of Zakat, it is explained about the conception of zakat utilization, namely (Fitri, 2017): (1) Zakat can be utilized for productive efforts in the framework of handling the poor and improving the quality of the people. (2) Utilization of zakat for productive business as referred to in paragraph (1) is carried out if the basic needs of mustahiq have been fulfilled.

The indicators of utilization (Ahmad Fajri Panca Putra) explained as follows (Putra, 2010). (1) Allocation of productive zakat funds: namely the accuracy of determining the amount of zakat funds given to mustahiq as capital or business development to be carried out in a certain area. (2) Targets of the utilization of productive zakat funds: namely the accuracy of the target mustahiq (people who receive) productive zakat to be used as their business capital, so that they can develop their businesses and live independently. (3) Distribution of productive zakat funds: namely the accuracy of the distribution system of productive zakat conducted by BAZNAS of South Sumatra Province to mustahiq who can receive productive zakat funds according to predetermined criteria to be used as business capital. 


\section{International Journal of Business Economics (IJBE)}

Vol, 2 Issue 1, pp 39-51, Sept 2020

http://jurnal.umsu.ac.id/index.php/ijbe

eISSN 2686-472X

According to Shardlow in Rahman Mulyawan said that "such a definition of empowerment is centrally about people taking control of their own lives and having the power to shape their own future" ie empowerment discusses how individuals, groups or communities try to control their own lives and try to shape the future according to their wishes (Mulyawan, 2016). Community empowerment according to the Chamber in Munawar Noor is the concept of economic development that encapsulates the values of society to build a new paradigm in people-centered, participatory, empowerment and sustainable development. Chamber explained that the concept of development with the community empowerment model does not merely fulfill the basic needs of the community but rather as an effort to find alternatives for local economic growth (Noor, 2011).

The purpose of empowerment refers to the ability of people, especially vulnerable and weak groups so that they have the ability and strength (Noor, 2011), Meeting their basic needs so that they have freedom (freedom) which means not only free in expressing opinions but free from hunger, free from pain, and free from ignorance, Reach productive resources that enable them to increase their income so that they obtain the goods and services they need, Can participate in the development process and decisions that affect them.

According to Schuler, Hashemi and Riley in Joko Hadi Purnomo developed several indicators of empowerment which they called the empowerment index (Purnomo, 2018). Freedom of mobility: the ability of individuals to go outside their homes or areas of residence, such as to markets, houses of worship, and so on. Ability to buy "small" commodities: the ability of individuals to purchase daily family needs items such as rice, kerosene, cooking oil, herbs and so on. Ability to buy "large" commodities: the ability of individuals to buy secondary or tertiary goods, such as buying motorbikes, gadgets, television and so on. Involved in making household decisions: able to make decisions alone or together with husband / wife regarding family decisions. Relative freedom from family domination: has it been forbidden to work outside, it is forbidden to go out at night, and so on. Legal and political awareness: knowing the name of a government apparatus, knowing the importance of having a KTP, and so on. Involvement in campaigns and protests: a person is considered "helpless" if he has been involved in a campaign or with other people protesting, for example, misuse of social assistance, or abuse of police and government employees' power and so on. Economic security and contribution to the family: owning a house, land, productive assets, and savings.

\section{Effect of Earning Zakat Management on Empowerment of Mustahiq}

Based on the "ACTORS" Theory of empowerment put forward by Sarah Cook and Steve Macaulay who more view the community as a subject who can make changes by freeing someone from rigid control and giving the person freedom to be responsible for his ideas, decisions, and its actions (Maani, 2011). This theory aims to help people to live independently. And in this theory there is an acronym " $\mathrm{R}$ " responsibilities (responsibility), namely in making changes must be through management so that it is done with full responsibility to change for the better. In terms of community empowerment, appropriate strategies are needed such as zakat management for the empowerment of mustahiq. With management, humans are able to practice effective and efficient ways of carrying out work. Likewise in the management of zakat, management can be used to plan, collect, utilize, and develop the acquisition of zakat funds effectively and efficiently. This shows clearly that management plays an important role in achieving organizational goals. 


\section{International Journal of Business Economics (IJBE)}

Vol, 2 Issue 1, pp 39-51, Sept 2020

http:/ /jurnal.umsu.ac.id/index.php/ijbe

eISSN 2686-472X

This is supported by the results of Evi Nurmalasari's research entitled Effect of Productive Zakat Management on Empowerment of Mustahiq on LAZISWA At-Taqwa Cirebon and research from Joko Hadi Purnomo entitled The Effect of Zakat Management on Poverty Alleviation with Zakat Empowerment and the Utilization of Zakat as a Moderating Variable (Study at the Foundation of Joko Hadi Purnomo) Social Fund Al Falah (YDSF) East Java Province). From these two studies, productive zakat management variables that are used have positive and significant effects on the empowerment of mustahiq.Based on the results of previous studies, the hypotheses in this study are as follows:

H1: Productive Zakat Management has a positive and significant effect on the Empowerment of Mustahiq.

\section{Effect of Empowerment on Empowerment of Mustahiq}

By using the framework of "ACTORS" namely authority (authority), confidence and competence (confidence and ability), trust (confidence), opportunities (opportunities), responsibilities (responsibility), support (support), in order to foster community empowerment, will be done by referring to the empowerment that comes from the inner and inter community. Where the government and non-government organizations as actors (Maani, 2011).

This theory explains that the role of government in empowerment is as its light, because the government is more authorized. The government in this case is the National Amil Zakat Agency (BAZNAS) of South Sumatra Province which has the authority to utilize zakat. In this theory there is the acronym " $\mathrm{C}$ " confidence and competence (self-confidence and ability), which raises self-confidence by seeing their ability to be able to change the situation and the acronym "O" opportunities (opportunities). This explains that the community is given the opportunity to be able to change their lives and their families by being given a venture capital from the utilization of productive zakat, so the community can develop the potential that exists within them. Utilization which has an important role in community empowerment, must be carried out as well as possible so that the purpose of such utilization can be fulfilled such as helping the community to be able to meet their needs, to be able to live independently and be equal with others.

This is supported by the results of Suratno's research entitled Effect of Utilization of Productive Zakat Funds on Empowerment of Mustahiq on the Amil Zakat Agency in Kuantan Singingi Regency (Application of Law Number 38 Year 1999) and Khadijah's research entitled Effect of Utilization of Productive Zakat Funds on Empowering Mustahiq on the Entity of Mustafaq Regency Amil Zakat Kuantan Singingi Regency (Application of Law Number 38 Year 1999). From these two studies, the utilization of productive zakat variables that are used both positively and significantly affects the empowerment of mustahiq. Based on the results of previous studies, the hypotheses in this study are as follows:

$\mathrm{H} 2$ : Productive Zakat Utilization has a positive and significant effect on Empowering Mustahiq. 


\section{International Journal of Business Economics (IJBE)}

Vol, 2 Issue 1, pp 39-51, Sept 2020

http://jurnal.umsu.ac.id/index.php/ijbe

eISSN 2686-472X

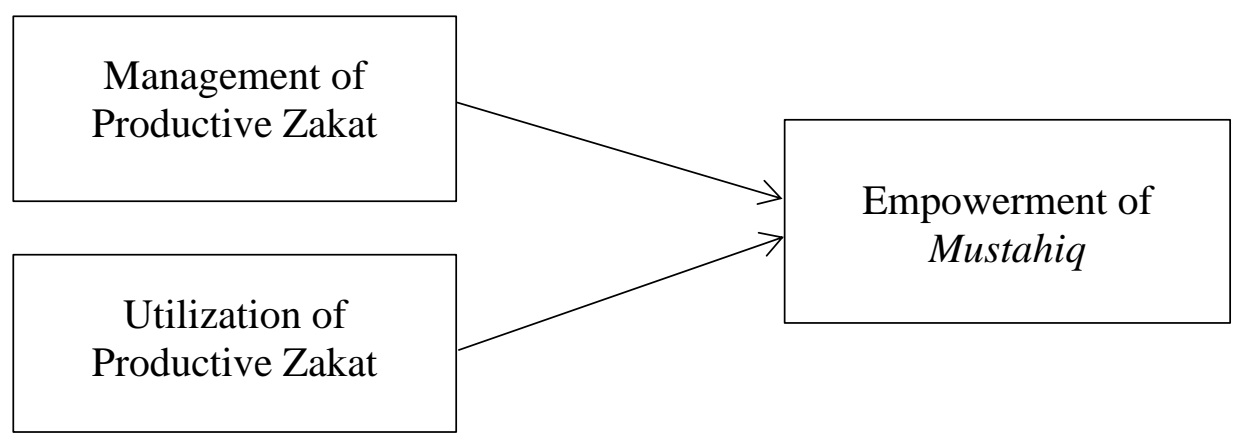

Figure 1. Conceptual Framework

\section{METHODS}

The population in this study were all productive zakat alms in the National Amil Zakat Board (BAZNAS) of South Sumatra Province, amounting to 30 productive zakat alms (BAZNAS, Mustahiq Data, 2019).

Sampling in this research is to use nonprobability sampling technique with saturated sampling technique, where this technique is a technique that uses all members of the population as part of the sample or used as samples to be examined. As for this study, the population of productive zakat mustahiq in the National Amil Zakat Board (BAZNAS) of South Sumatra Province, amounting to 30 people of productive zakat mustahiq.

The variables in this study are as follows: Independent Variable (X). The independent variable (influence) is also called the independent variable is the variable that plays a role in influencing other variables. In this study, the independent variables are Productive Zakat Management (X1) and Productive Zakat Utilization (X2). Indicators of Productive Zakat Management: Planning, Organizing and Staffing, Organizing and Directing, Control, Communication, Procurement / Subcontracting, Spaces and Facilities Space and Facilities). Indicators of Productive Zakat Utilization: Allocation of productive zakat funds, targets for the utilization of productive zakat, and distribution of productive zakat funds. Dependent Variable (Y), The dependent variable (affected) is also called the dependent variable is a variable that is used as a factor that is influenced by a number of other variables. In this study, the dependent variable is Empowerment Mustahiq (Y) (Raudhah, 2017), Indicators of Empowerment: Freedom of mobility, ability to buy "small" commodities, ability to buy "large" commodities, involved in making household decisions, relative freedom from family domination, legal and political awareness, involvement in campaigns and protests, economic security and contribution to the family. 


\section{International Journal of Business Economics (IJBE)}

Vol, 2 Issue 1, pp 39-51, Sept 2020

http://jurnal.umsu.ac.id/index.php/ijbe

eISSN 2686-472X

RESULTS AND DISCUSSION

Tabel 2 Classic assumption test

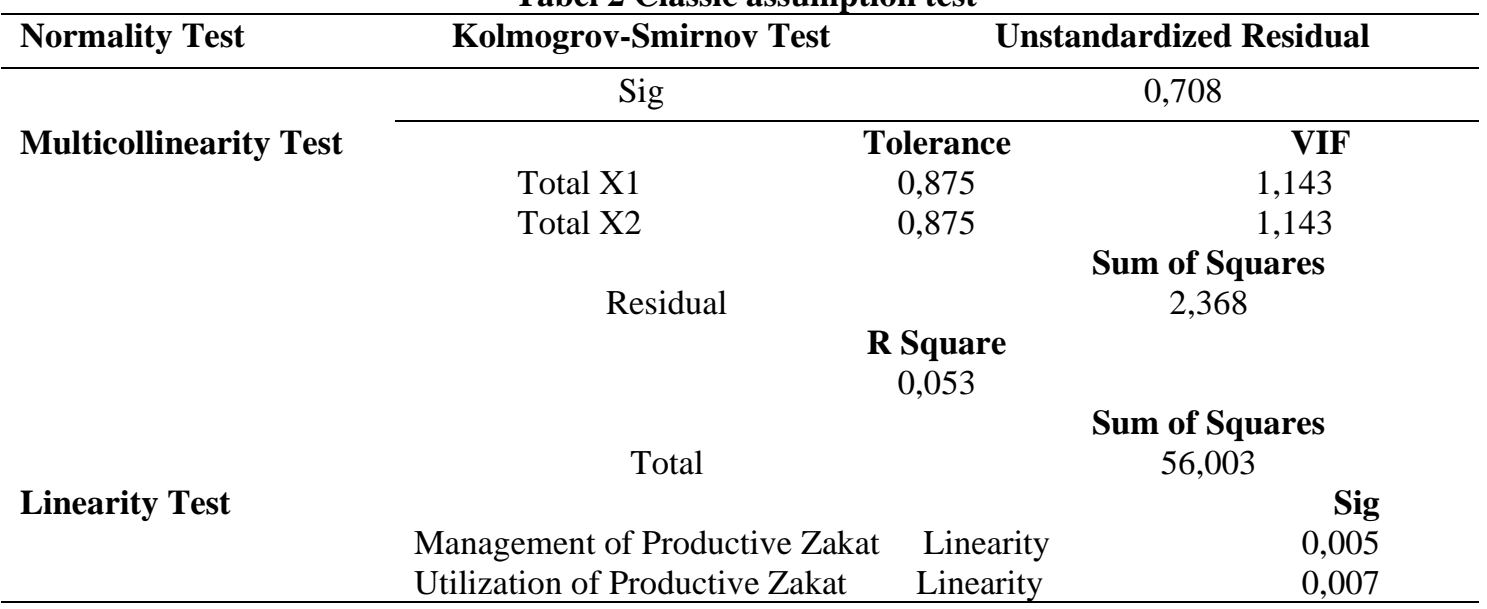

Using the Kolmogrov-Smirnov method. Based on the table above, it can be seen that the data is normally distributed, namely Asymp. Sig. > 0.05. Thus, it can be concluded that the residual data are normally distributed and the regression model meets the normality assumption.

Based on the table above it is known that the tolerance value of all independent variables > from 0.1. Value of the Variance Inflation Factor (VIF) of the three variables < out of 10. Based on the criteria in decision making, it can be concluded that there is no multicollinearity.

Using the Bresch-Pagan-Godfrey (BPG) method is performed by regressing all the independent variables on the value of $\rho 1$. The value of $\rho 1$ is obtained from the residual $\frac{\text { residual }}{\mathrm{n}}=\frac{2,368}{30}=0,0789$ where the residual is seen from the Sum of Squares and $n$ is the amount of data. If the Chi Square count < Chi Square table, then in the model there is no heteroscedasticity problem. Chi Square value calculated in this method is obtained from $\frac{\mathrm{R}^{2} \times \mathrm{TSS}}{2}=\frac{0,053 \times 56,003}{2}=1,48$ where TSS is the Total Sum of Square. Based on the data above, it can be seen that the regression model does not occur heteroscedasticity symptoms. This is because the calculated Chi Square value $(1,48)<$ Chi Square table $(40,113)$.

Using the Test for Linearity at a significance level of 0,05 . Two variables are said to have a linear relationship if the significance (Linearity) $<0,05$. Based on the above table, the Sig. Linearity of $0.005<a=0.05$ (management) and the Sig. Linearity of $0.007<a=0,05$ (utilization), meaning that linear regression can be used to explain the effect of management and utilization of productive zakat on empowering mustahiq.

Table 3. Coefficients

\begin{tabular}{cc}
\hline & \multicolumn{2}{c}{ Unstandardized Coefficients } \\
\cline { 2 - 2 } (Constant) & $\mathrm{B}$ \\
Total X1 & 1,315 \\
Total X2 & 0,385 \\
\end{tabular}




\section{International Journal of Business Economics (IJBE)}

Vol, 2 Issue 1, pp 39-51, Sept 2020

http:/ /jurnal.umsu.ac.id/index.php/ijbe

eISSN 2686-472X

Based on table 1.2 the regression coefficients of each variable are obtained with the help of SPSS version 16 to get the multiple linear regression equation can be written as follows: $\mathrm{Y}=\mathrm{a}+\mathrm{b}_{1} \mathrm{X}_{1}+\mathrm{b}_{2} \mathrm{X}_{2} ; \mathrm{Y}=1,315+0,385 \mathrm{X}_{1}+0,295 \mathrm{X}_{2}$.

From this equation it can be predicted that the mustahiq empowerment variable will change by 0,385 for each unit of change that occurs in the productive zakat management variable, and the mustahiq empowerment variable will change by 0,295 for each unit change that occurs in the productive zakat utilization variable.

Table 4. Hypothesis Test

\begin{tabular}{cccc}
\hline & Model & F & Sig \\
\hline \multirow{2}{*}{ F Test } & $\begin{array}{c}\text { Regression } \\
\text { Residual }\end{array}$ & 9,386 & $0,001^{\mathrm{a}}$ \\
& Total & & \\
& Model & T & Sig. \\
\cline { 2 - 4 } T Test & (Constant) & 1,874 & 0,072 \\
& Total X1 & 2,597 & 0,015 \\
& Total X2 & 2,325 & 0,028 \\
Determinant & & R Square & \\
Coefficient Test $\left(\mathbf{R}^{2}\right)$ & & 0,410 & \\
\hline
\end{tabular}

If $F_{\text {count }}>F_{\text {table, }}$, then Ho is rejected and $\mathrm{Ha}$ is accepted and vice versa if $F_{\text {count }}<F_{\text {table }}$, then Ho is accepted and $\mathrm{Ha}$ is rejected. From the calculation results, the numbers are obtained $F_{\text {count }}$ sebesar 9,386 > $F_{\text {table }}$ amounted to 3.35 so that Ho was rejected and Ha was accepted. Thus, the regression model is feasible and correct. This means that the management and utilization of productive zakat simultaneously affect the empowerment of mustahiq. The effect is $41 \%$ and the significance of $0.001<\mathrm{a}=0.05$. The influence of other variables outside the regression model is calculated by the formula: $(1-\mathrm{R} 2)$ or $(1-0,410)=0.59$ or $59 \%$.

If $t_{\text {count }}>t_{\text {table, }}$ then Ho is rejected and Ha is accepted and vice versa $t_{\text {count }}<t_{\text {table, }}$, then Ho is accepted and $\mathrm{Ha}$ is rejected. The magnitude of the numbers $\mathrm{t}_{\text {table }}$ under the condition a $=0,05$ and $\mathrm{dk}=(\mathrm{n}-\mathrm{k})$ or $(30-3)=27$. From these provisions a ttable number of 1.703229 was obtained. The Effect of Earning Zakat Management on Empowerment of Mustahiq. Based on the calculation results, the tcount is obtained $2.597>\mathrm{t}$ table 1.703229 , so that Ho is rejected and $\mathrm{Ha}$ is accepted. That is, there is an influence between the management of productive zakat on the empowerment of mustahiq. The magnitude of the effect of managing productive zakat on empowering mustahiq $=0.385$ or $38.5 \%$ is considered significant with a significance level of $0.015<\mathrm{a}=0.05$. The Effect of Productive Zakat Utilization on Empowerment of Mustahiq. Based on the results of the calculation, the tcount is obtained 2,325 > t table 1.703229, so that Ho is rejected and Ha is accepted. That is, there is an influence between the utilization of productive zakat on the empowerment of mustahiq. The magnitude of the effect of utilizing productive zakat on empowering mustahiq $=0.295$ or $29.5 \%$ is considered significant with a significance level of $0,028<a=0,05$.

Based on the table above, shows that the independent variable is only able to explain the dependent variable by $41 \%$, while the remaining $59 \%$ is explained by other variables which was not included in this study. The results of the coefficient of determination test mean that there are still other independent variables that influence the empowerment of mustahiq. For this reason, further research is needed in relation to this topic. 


\section{International Journal of Business Economics (IJBE)}

Vol, 2 Issue 1, pp 39-51, Sept 2020

http://jurnal.umsu.ac.id/index.php/ijbe

eISSN 2686-472X

\section{Discussion \\ Effect of Earning Zakat Management on Empowerment of Mustahiq}

Based on the test results, it is known that the management of productive zakat has a positive and significant effect on the empowerment of mustahiq. Supported by the theory of "ACTORS" which explains the management of productive zakat is the process, organizing socialization, collection, distribution, and supervision in the implementation of zakat. Based on the theory of "ACTORS" about empowerment put forward by Sarah Cook and Steve Macaulay, they look more at society as a subject that can make changes (Maani, 2011).

In making changes, it must be managed so that it is carried out with full responsibility to change for the better. The right strategy is needed such as zakat management for empowering mustahiq in terms of empowering mustahiq. With the management, humans are able to practice effective and efficient ways of carrying out work. Likewise in the case of zakat, management can be used to plan, collect, utilize, and develop the acquisition of zakat funds productively to be even more useful. This shows clearly that management plays an important role in achieving organizational goals.

This is consistent with the results of research by Evi Nurmalasari and Joko Hadi Purnomo which concluded that the variable management of productive zakat has a positive and significant effect on the empowerment of mustahiq.

\section{The Effect of Productive Zakat Utilization on Mustahiq Empowerment}

Based on the test results, it is known that the utilization of productive zakat has a positive and significant effect on the empowerment of mustahiq. Supported by ACTORS theory, that the utilization of zakat in principle is related to the technical distribution of zakat to be right on target and efficient for the recipient of zakat (mustahiq). By using the framework of "ACTORS" namely authority (authority), confidence and competence (confidence and ability), trust (confidence), opportunities (opportunities), responsibilities (responsibility), support (support), in order to foster community empowerment, where the government and non-government organizations as actors (Maani, 2011). Then (Nasution \& Prayogi, 2019) Irfan argues that productive Zakat affects the welfare of mustahik. Zakat has the potential to alleviate poverty, because in zakat there is a principle of social justice and will affect to improve the welfare of mustahik if it is used according to its usefulness, and zakat is also a solution to reduce poverty.

This explains that the role of the community especially the government in empowerment is very important, because the government is more authorized. The government in this case is the National Amil Zakat Agency (BAZNAS) of South Sumatra Province which has the authority to utilize zakat. The community is given the opportunity to be able to change their lives and their families by being given a business capital from the utilization of productive zakat, so the community can develop the potential that exists within themselves. Utilization which has an important role in community empowerment, must be carried out as well as possible so that the purpose of such utilization can be fulfilled.

This is in accordance with the results of Suratno and Khadijah's research which concluded that the variable utilization of productive zakat has a positive and significant effect on the empowerment of mustahiq.

\section{CONCLUSION}

Based on the results of research and discussion of the testing of the influence of the management and utilization of productive zakat on the empowerment of mustahiq in the National Amil Zakat Agency (BAZNAS) of South Sumatra Province and supported by the 


\section{International Journal of Business Economics (IJBE)}

Vol, 2 Issue 1, pp 39-51, Sept 2020

http:/ /jurnal.umsu.ac.id/index.php/ijbe

eISSN 2686-472X

theory of "ACTORS" in empowerment, the authors conclude that: The Effect of Earning Zakat Management on Empowerment of Mustahiq, Management Management of productive zakat has a positive and significant effect on the empowerment of mustahiq in the National Amil Zakat Agency (BAZNAS) of South Sumatra Province. On the variable of productive zakat management, the questionnaire score results table with the majority of respondents on the choice of answers gives results (strongly agree and agree) which proves that the National Amil Zakat Board (BAZNAS) of South Sumatra Province is good in terms of productive zakat management. The Effect of Productive Zakat Utilization on Empowerment of Mustahiq, Utilization of productive zakat has a positive and significant effect on the empowerment of mustahiq in the National Amil Zakat Agency (BAZNAS) of South Sumatra Province. On the variable utilization of productive zakat, the results table of questionnaire scores with the majority of respondents on the choice of answers gives results (strongly agree and agree) which proves that the National Amil Zakat Board (BAZNAS) of South Sumatra Province is already good in terms of utilizing productive zakat.

Based on the above conclusions, the following suggestions can be submitted: The management performance of the National Amil Zakat Agency (BAZNAS) of South Sumatra Province has been good, in terms of planning, distribution and utilization of zakat funds productively. Management and utilization that is done is already modern but does not leave the sharia elements in it. However, to be more widely known for its successful management and utilization, the National Amil Zakat Agency (BAZNAS) of South Sumatra Province should always pay attention in terms of providing services, distribution and facilities to productive zakat mustahiq periodically and pay more attention to the development of mustahiq after receiving business assistance. BAZNAS must also pay more attention to the responsibility of the successful management and utilization made for the progress of the developed mustahiq. For mustahiq, in using productive zakat funds that have been given to be truly managed for serious businesses and to pursue their businesses in order to improve the economy, not used for less valuable consumptive activities so that the objective of productive zakat funds is achieved in terms of empowering mustahiq. It is expected to develop this research by adding other variables that influence the empowerment of mustahiq.

\section{REFERENCES}

Abdullah, Yudi. 2019. Masyarakat diimbau BAZNAS Sumsel Bayar Zakat di Lembaga Resmi.Khasanah, Umrotul. 2010. Manajemen Zakat Modern Instrumen Pemberdayaan Ekonomi Umat. Malang: UIN-Maliki Press.

Arifin, Gus. 2016. Keutamaan Zakat, Infak, Sedekah. Bandung: PT Gramedia.

Aziz, Abdul dan Rizki. 2019. "Pengaruh Pengelolaan Zakat, Infaq dan Shadaqah terhadap Pemberdayaan Ekonomi Masyarakat di BAZNAS Kota Cirebon".

Badan Amil Zakat Nasional, diakses dari https://baznas.go.id pada tanggal 21 Mei 2019 pukul 08.00 WIB.

Badan Amil Zakat Nasional. 2016. Kompilasi Peraturan Perundang-Undangan Pengelolaan Zakat. Jakarta: Badan Amil Zakat Nasional.

El-Madani. 2013. Fiqh Zakat Lengkap. Yogyakarta: Diva Press.

Fitri, Maltul. 2017. Pengelolaan Zakat Produktif sebagai Instrumen Peningkatan Kesejahteraan Umat. Jurnal Ekonomi Islam. Vol. 8, No. 1.

Hasanah, Umrotul. 2010. Manajemen Zakat Modern Instrumen Pemberdayaan Ekonomi Umat. Malang: UIN-Maliki Press. 


\section{International Journal of Business Economics (IJBE)}

Vol, 2 Issue 1, pp 39-51, Sept 2020

http://jurnal.umsu.ac.id/index.php/ijbe

eISSN 2686-472X

Maani, Karjuni Dt. 2011. Teori ACTORS dalam Pemberdayaan Masyarakat. Vol. 10, No. 1.

M. Richard. 2019. Potensi ZRp200 Triliun, KNKS baru gaet Rp8 Triliun. Diakses dari https://m.bisnis.com/amp/read/20191112/90/1169668/potensi-zakat-mencapai-r pada tanggal 13 November 2019 pukul 07.10 WIB.

Mulyawan, Rahman. 2016. Masyarakat, Wilayah dan Pembangunan. Bandung: UNPAD PRESS.

Nasution, M. I., \& Prayogi, M. A. (2019). The Utilization of Zakah Productive towards Micro-Business Growth and Mustahik Welfare. Jurnal Ekonomi Pembangunan: Kajian Masalah Ekonomi Dan Pembangunan, 20(1), 1-11. https://doi.org/10.23917/jep.v20i1.6576

Noor, Munawar. 2011. Pemberdayaan Masyarakat. Vol. 1, No. 2.

Nurmalasari, Evi. 2012. Skripsi "Pengaruh Pengelolaan Zakat Produtif terhadap Pemberdayaan Mustahiq pada LAZISWA At-Taqwa Cirebon”. Cirebon: Fakultas Syariah dan Ekonomi Islam IAIN Syekh Nurjati. Diakses tanggal 29 Oktober 2019 pukul 12.56 WIB.

Proyek Peningkatan Pemberdayaan Zakat Direktorat jenderal Bimbingan Masyarakat Islam dan Penyelenggara Haji Departemen Agama RI. 2004. Manajemen Pengelolaan Zakat.

Purnomo, Joko Hadi. 2018. Skripsi "Pengaruh Pengelolaan Zakat terhadap Penanggulangan Kemiskinan dengan Pemberdayaan Zakat dan Pendayagunaan Zakat sebagai Variabel Moderating (Studi di Yayasan Sosial Dana Al-Falah (YDSF) Provinsi Jawa Timur”. Surabaya: UIN Sunan Ampel Suarabaya. Diakses tanggal 29 Oktober 2019 pukul 13.04 WIB.

Putra, Ahmad Fajri Panca. 2010. Skripsi: "Pengaruh Pendayagunaan Zakat Produktif terhadap Pemberdayaan Mustahiq pada Badan Pelaksana Urusan Zakat Amwal Muhammadiyah (BAPELURZAM) Pimpinan Cabang Muhammadiyah Weleri Kabupaten Kendal". Semarang: Fakultas Syariah IAIN Walisongo. Diakses tanggal 29 Oktober 2019 pukul 13.01 WIB.

Qaradhawi, Yusuf. 2005. Spektrum Zakat dalam Membangun Ekonomi Kerakyatan. Jakarta: Daar El-Syoruk.

Raudhah. 2017. Variabel Penelitian. Vol. 5, No. 2.

Rosmawati, Rosi. 2014. Pengembangan Potensi Dana Zakat Produktif Melalui Lembaga Amil Zakat (LAZ) untuk Meningkatkan Kesejahteraan Masyarakat. Vol. 1, No. 1.

Sugiyono. 2017. Metode Penelitian Kuantitatif, Kualitatif, dan R\&B. Bandung: Alfabeta.

Suratno. 2017. Skripsi: "Pengaruh Pendayagunaan Zakat Produktif terhadap Pemberdayaan Mustahiq". Fakultas Ekonomi dan Bisnis Islam UIN Raden Intan Lampung. Diakses pada tanggal 29 Oktober 2019 pukul 13.06 WIB.

Syahriza, Mulkan dkk. 2019. Analisis Efektivitas Distribusi Zakat Produktif dalam Meningkatkan Kesejahteraan Mustahik (Studi Kantor Cabang Rumah Zakat Sumatera Utara). Vol. 4, No. 1. 